\title{
Gender Issues in Human, Animal and plant health using an Ecohealth Perspective
}

\author{
Brigitte Bagnol $^{1,4}$, Robyn Alders ${ }^{2,5,6} \&$ Robyn McConchie ${ }^{3}$ \\ ${ }^{1}$ Department of Anthropology. The Witwatersrand University, Johannesburg, South Africa \\ ${ }^{2}$ Faculty of Veterinary Science and Charles Perkins Centre, University of Sydney, Australia \\ ${ }^{3}$ Plant and Food Sciences, Faculty of Agriculture and Environment, The University of Sydney, Australia \\ ${ }^{4}$ Department of Environmental and Population Health, Cummings School of Veterinary Medicine at Tufts \\ University, USA \\ ${ }^{5}$ International Rural Poultry Centre, KYEEMA Foundation, Australia \\ ${ }^{6}$ Department of Infectious Disease and Global Health, Cummings School of Veterinary Medicine, Tufts \\ University, USA \\ Correspondence: Brigitte Bagnol, Department of Environmental and Population Health, Cummings School of \\ Veterinary Medicine at Tufts University, USA. E-mail: bagnolbrigitte@gmail.com
}

Received: September 9, 2014 Accepted: September 25, 2014 Online Published: February 20, 2015

doi:10.5539/enrr.v5n1p62

URL: http://dx.doi.org/10.5539/enrr.v5n1p62

\begin{abstract}
The ecohealth approach is a core concept integrating environmental aspects with human and animal health (domestic and wild animals). Zoonotic and emerging diseases affect human health and impact negatively on food security. Although both the risk of contracting a disease and the subsequent impacts vary between different genders, age groups, cultures and social conditions, very little research has been done on this and few guidelines or interventions focus adequately on these aspects. This paper is based on a conceptual framework identifying the relationship between gender inequalities and the risk of contracting a disease in an ecohealth perspective. It looks at the varying impacts of plant, animal and human diseases and identifies four contributing factors.

This paper first discusses the socially defined roles including social, economic, cultural, legal and political factors that often determine which place men and women occupy in society, which animals and plants men or women have accumulated knowledge of, which they have control of and which they benefit from and consequently the impact men and women have on the environment due to these specific roles. Secondly, it analyses the gender differences in risk of infection. It also analyses cultural differences that influence practices connected to animal, plant and human diseases and discusses respective preventions and treatments. Thirdly, it also identifies the ways men and women are impacted by the diseases of human, plants and animals in different ways. Lastly, this paper assesses the biological factors that influence the differences in exposure, infection rates and mortality rates between men and women during their life cycle. These four factors contribute to gender variations in relation to animal, human, plant and ecological health.
\end{abstract}

Keywords: gender, conceptual framework, risk, impact, disease, factors, ecohealth

\section{Introduction}

The rise in the global population has had a profound effect on the interaction between people, domestic animals and wildlife, and has led to accrued land use for livestock and agriculture, increased livestock production, accelerated encroachment on wildlife habitat, redoubled demand for natural resources, and increased population movement, both international and local. The emergence and re-emergence of zoonotic diseases such as Rift Valley fever, highly pathogenic avian influenza (HPAI), HIV/AIDS, Ebola virus, Brucellosis and Tuberculosis are examples of this increasing interdependence between the environment, the people and their agricultural endeavours to feed the population. The ecohealth approach, integrating environmental aspects (including plant health) with human and animal health (including domestic and wild animals) (AVMA, 2008) recognizes the inter-dependency between these three systems and maintains that a multisectoral collaboration has to be promoted and new policies, systems and processes have to be put in place in order to prevent the spread of such diseases. 
Charron (2011) identified six pillars to ecohealth required to frame an effective research process when tackling complex problems and to aid in the application of the results: systems thinking, transdisciplinary research, participation, gender and social equity, sustainability, and knowledge to action. While several reports have highlighted the importance of gender issues on various facets of health (WHO, 2007), agriculture (Saito \& Spurling, 1992; FAO, 1995. 1996; SOFA team \& Doss, 2011) and the environment (Shiva, 1989, 1997) very little research, and few guidelines or interventions focus adequately on the relationship between plant, animal and human health and the environmental aspects that contribute to this. Addressing gender issues is both holistic and transdisciplinary, and therefore offers a unique transversal lens through which to understand ecohealth. Gender is an essential element to be addressed if the ecohealth paradigm is to realize its potential.

Despite problems with generalisation and the importance of affirming that each situation needs to be analysed within its specific context, it can be stated that gender is fundamental to the ecohealth approach for several reasons (Figure 1). First, the risk of infection differs between women and men (WHO, 2007). For example, in the case of diseases in animals, plants and humans, the different access and control over resources between men and women and their different role and responsibilities in society and in the household directly impacts the effect of the disease on them. Gender also influences the likelihood of accessing information and treatment, the resources required to get access to treatment, the evolution of the disease and the outcome of the treatment. There is little biomedical knowledge on the effect of treatment between men and women, which has not been fully researched or understood (WHO, 2007). More knowledge has been accumulated on the diseases of plants and livestock under the care of men than on those cared for by women (Lofstedt, 2003). The focus of agricultural research and extension activities has also generally been on commercial crops usually under the control of men rather than the subsistence crops under the responsibility of women (FAO, 1996). When surveillance, control and responses to disease are designed without gender sensitivity, they are less likely to encompass a full understanding of the causes, consequences and implication of the diseases and consequently to design adequate solution (WHO, 2007).

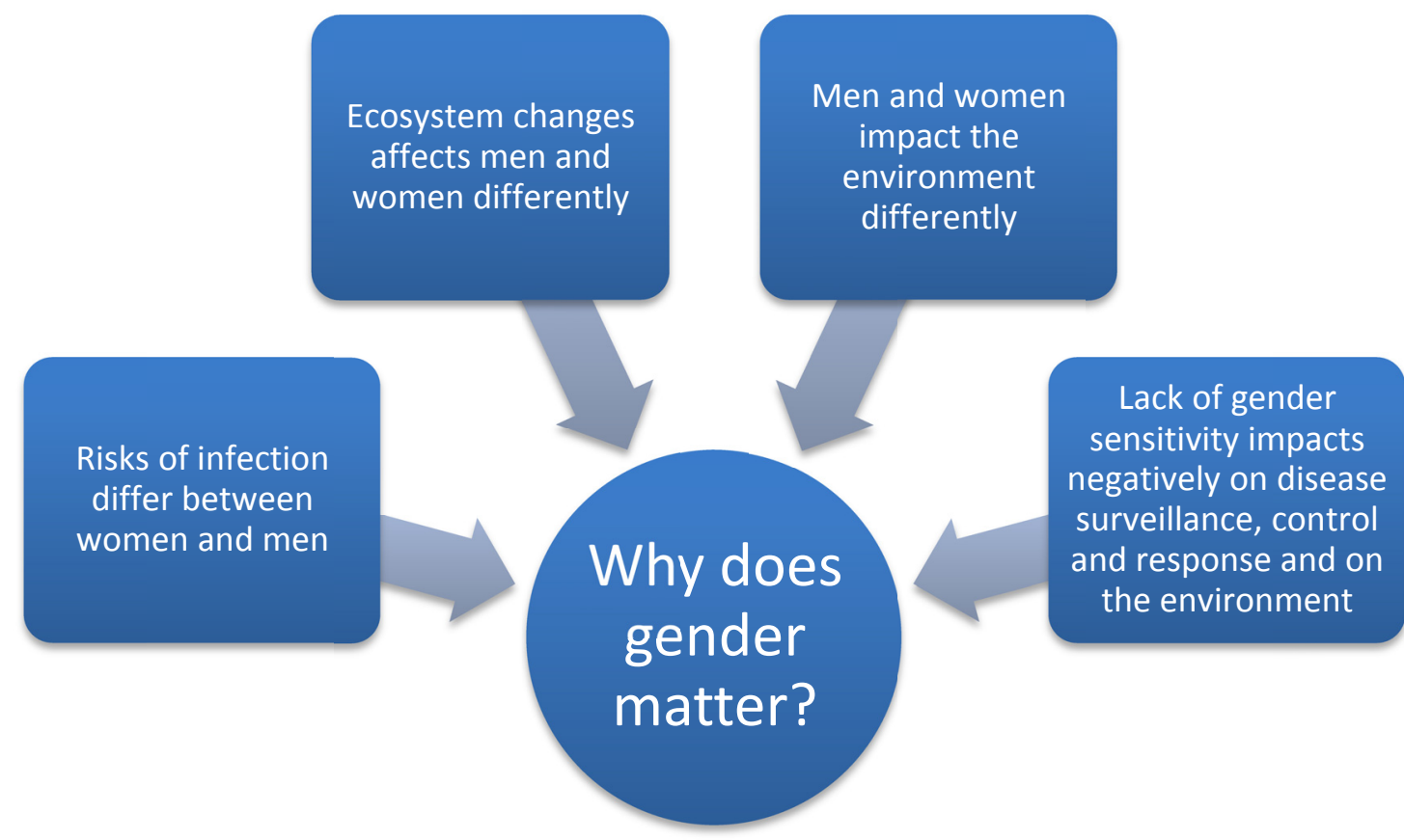

Figure 1. Why does gender matter in the ecohealth approach?

This paper proposes a conceptual framework that identifies four factors that contribute to gender inequities in relation to animal, plant and human health issues. Firstly, the social, economic, legal cultural and political factors that influence how men and women impact differently on the environment. Secondly, differences in the levels of risk between men and women, are interconnected with the inequality in access to information, education and economic activities that limits women's earning capacity and contributes to unequal income distribution between men and women. It also affects the opportunities women have to access relevant information relating to disease prevention and treatment. Additionally, women's limited participation in decision-making exacerbates their invisibility and often results in women's issues not being adequately analysed and integrated thus increasing their 
risk to be adversely affected by ecological disasters and problems. Thirdly, socially defined roles often determine the animals and plants about which men and women have accumulated knowledge, control over and from which they directly benefit. Consequently, ecological degradation, plant and animal diseases affect men and women differently both in terms of their risk of infection and their level of socio-economic impact. Fourthly, biological factors influence differences in exposure, infection rates and mortality rates of men and women during their life cycle. These four factors contribute to gender variations in relation to animal, human, plant and ecological health. The complexity of ecohealth requires new ways of interacting and working to transition from multidisciplinary to transdisciplinary approaches.

\section{Social, Economic, Legal, Cultural and Political Factors Influences how Men and Women Impact the} Environment

The relations of men and women with nature, are not based on biological characteristics, but on social and ideological construction (Leach, 2007: 70; Gagné, 2010: 41) that needs to be understood to provide information on the way men and women impact the environment and vice versa. Because of their different gender roles and power in society men and women impact the environment differently. Economic, cultural, religious, legal and political aspects influence the ability of girls and women to fully exercise control over their environment, their health, and the health of their children, animal and plants. In general, women have less access to resources such as information, education, labour, land, decision making, etc., which contributes to the lower economic and social power of both girls and women and limits their possibility to define how to relate to the environment. While men tend to define the policies related to development and associated environmental impact, women, and more specifically poor women, are simply left to deal with the consequences of those decisions.

In the last decades rising human population has lead to increased land use for agriculture, in livestock production and in demand for natural resources. Population movement across the globe, globalisation and accelerated encroachment on natural habitats has seriously impacted on ecosystems leading to the degradation of the environment with increased atmospheric concentration of carbon dioxide, climate change and the emergence of new diseases, including zoonoses. Often, people live in environments that are harmful to their health and they face malnutrition (both under and over nutrition) and environmental pollution. These problems are not only in developing countries but also in the built environment in urban areas of the developed. Obesity, diabetes, asthma, and heart disease are all directly related to how humans interact with the urban ecosystem in which they live. Urban planning and design determines the transport used, the food available, the air pollution levels and the life style. Public-health and animal-health professionals, anthropologists, conservationists and ecologists are trying to address these aspects but a more transdisciplinary approach is needed. Western science and epistemiologies that were perceived as a source of unquestioned truth until recently are now analysed to highlight their failure and their negative impact both on nature, marginalized economies and on women. Some authors analyse the links between the gender inequalities and the ecological crisis (Braidotti, Charkiewicz, Hausler, \& Wieringa, 1994). The male dominated theories and instruments used to exert domination on nature and on people (specifically women often seen as part of nature due to their reproductive role) are questioned as they are understood to be the causes of the depletion of the earth's resources, the increased poverty, especially for women. For example, in Sub Saharan Africa women play a dominant role in the production, processing and post-harvest storage of the food and yet only 15 percent of landholders are women. Women also receive less than 10 percent of financial credit distributed and 7 percent of extension services (Dutta, 2005; Maass Wolfenson, 2013). Most interventions following outbreaks of plant, animal and human diseases and ecological disasters are carried out through imposing a "Western", "modern" and "rational", view (De Sousa Santos, 2007; Latour, 2012), without taking the local contexts and perspectives into consideration. Local communities may have different reasons for interpreting the etiology of disease (Green, 1999). in a different way to the biomedical practitioners and this is often overlooked This has profound implications for the prevention, treatment and the sharing of information about human, animal and plant diseases. This also impact negatively on women who are often the major victims of these problems.

An example of this is water management in Mozambique. Despite the fact that female farmers have a key role in the household economy, that they are the main catchers of water in the household (around $93 \%$ of women against 2\% of men and 5\% for children) (Ministério de Obras Públicas e Habitação, Direcção Nacional de Água, Programa Nacional de Água e Saneamento Rural, 2012) and are often the ones taking care of sanitation, their contribution and their knowledge as well as their economic empowerment, are not always taken into consideration when it comes, for example, to sustainably manage water resources.

Development options and the allocation of water to certain productive sectors over others are interventions that impact men and women differently. The pollution of rivers due to mining, the granting of land to private farmers 
that fence it, or the construction of tourism infrastructure, which forbid direct access to primary water sources to women is already affecting the daily lives of rural communities (Borges et al, 2011). With climate change and increasing water use in neighboring countries, the availability of water is tending to decrease. The decrease in water used for household consumption, for irrigation, for fishing, is greatly affecting women and, consequently, household wellbeing.

Prioritizing irrigation for the production of sugar cane around the Pungwe River instead of creating irrigation systems to smallholder sector tends to favor male employment at the expense of improving the family farm and, consequently, the work performed by women. Thus, the gender strategy of the agrarian sector (Ministry of Agriculture, Gender Unit of MOA, 2005) advocates "the promotion of small-scale irrigation projects integrating women as beneficiaries and with women participating in its management in a sustainable manner" in order to reduce poverty and empower women. The conversion of rainfed agriculture into irrigated agriculture, can greatly reduce the food insecurity of households, help reduce rural poverty and mitigate climate change. This recommendation tries to mitigate the negative impact of the exclusion of women from the discussion about national policies, from the benefits of the interventions developed. In the Mozambican National Directorate of Water the participation of women has increased from 24.5\% in 1994 (CBE Consultores, 2005) to 40,2\% in 2012. However, women tend to work in administrative aspects while men are a decision level. At provincial level, the percentage of women drops to around 3\%. A very small number of women participate in dam and river basin committees. When they are in water committees they are often responsible for hygiene and committee administration but not the head of the committees. Although the women are important users of the water resources they are seldom involved in the decision taken around the management of water. As a consequence of women not being involved in decision making in relation to issues that concern them, the water resources are used inadequately and the infrastructure are not adapted to their needs.

Most projects and programmes are designed without the participation of women and even without the consultation of women. Consequently women's knowledge and problems are not taken into consideration. This results in projects and programmes that impact nature in ways that women are not always conscious of and that do not provide solutions to women's constraints and needs. Projects are thus more likely to employ men, give them more access to resource, power and knowledge and reinforce power inequities. Thus, projects, as well as institutions and the state, are not gender neutral. Understanding the consequences of such practices is of extreme importance.

\section{Men and Women Experience Different Health Risks}

A complex web of marginalisation, poverty and other vulnerabilities determine a certain lack of control for many women and men over their life and health. In different socio-economic, racial and cultural contexts the situation may vary greatly and these differences need to be taken into consideration for the development of localized analysis and the resulting solutions. In many countries girls have less access to education than their male colleagues. The 2013 Millennium Development Goals Report from the United Nations indicates that girls in the less wealthy groups and in rural areas are less likely to access education than in wealthy and urban setting (UN, 2013). Access to education for a woman is considered to be the best predictor of her children's health compared to access to land, household assets or their father's education (Wamani, Tylleskär, Astrøm, Tumwine, \& Peterson, 2004), and therefore limitation to the education of girls is a gendered risk factor for the poor health of children. Each year of education of the mother reduces the likelihood of her child's growth being stunted between 4 to 5 percent (Semba et al., 2008). One study pointed out that women's education contributed to $43 \%$ of the reduction in child malnutrition over time (Smith \& Haddad, 2000). Thus, the lack of access to education through gender inequalities is, in this case, a contributing cause of malnutrition.

Overall, it is recognized that poverty is a predictor of poor health (Farmer, 1999) and that bad health and bad nutrition contribute to poor school attendance (Miguel \& Kremer, 2003). Undernutrition negatively influences intellectual and physical capacities, affects labour productivity and the ability of the undernourished to make a living, thus perpetuating a poverty and undernutrition cycle. Undernourished boys and girls do not perform as well in school as compared to their well-nourished peers, and as adults, they are less productive and earn lower wages. In countries where girls have less access to school and less access to adequate food, they are more likely to have a lower income and consequently, poor health.

Access to human health services depends on several factors including gender, economical resources, religion and education. While women regularly go to the health center when they are pregnant or with young children for weighing or immunization, they are less likely than men to go to the health center for their own health problems. In most situations, women do not have the economic resources, or, when there are resources in their households, the control over them to enable them to decide whether to seek treatment or to buy medication for themselves and their 
children. In some cases with particular norms of social behavior, women may not have the decision-making authority to take their children to the health center and to consult the health center for their own health issues and may require a formal authorization from their male partner.

Lack of equality in access to information, education and economic activities (UN, 2013) limits women's earning capacity, contributes to the unequal income distribution between men and women and consequently to the set of resources necessary to access treatment. This includes resources such as financial resources, access to information and the autonomy to take decisions. Women also have less decision-making power. An example of this situation is their limited participation in parliament as an expression of their contribution to leadership and policy development in society (Paxton, Green \& Hughes, 2008; World Bank, 2012 (http://devpolicy.org/want-a-strong-economy-electing-females-can-help20120529/proportion-of-women-in-parli ament-by-region/)).

The limitations experienced by women are not restricted to their physical health but also impact their activities as crop and livestock producers. Although women provide $90 \%$ of the labour to produce rice in Southeast Asia and $80 \%$ of the basic food in Africa (FAO, 2009a), the UN Food and Agriculture Organization (FAO) has found that women represent only $15 \%$ of the extension agents worldwide, female farmers receive only $5 \%$ of all agricultural extension services across 97 countries, and only $10 \%$ of total aid for agriculture, forestry and fishing goes to women (http://www.fao.org/gender/infographic/en/). Women have less access to inputs such as improved seeds, fertilizers and equipment and, as a result, their yield is lower than those of men (http://www.fao.org/gender/infographic/en/). Women also have less opportunity to access inputs and markets (Njuki, 2012) a situation that negatively affects the possibilities of yield improvement. Patterns of ownership of land also limit yield improvement by women, as they do not always have the final decision regarding the adoption of new crop production technologies. Because women represent a high proportion of producer and livestock keepers and because they have been sidelined from access to information and input, they are more likely to be impacted more seriously than their male counterparts in the event of animal and plant disease. This situation is the result of social practices and policies that discriminate women.

Cultural aspects are intrinsically interwoven with the social, economic, religious and political factors and may exacerbate gender differences, both in terms of the risk of contracting diseases and the opportunities for receiving or giving adequate treatment (Blum, Khan, Nahar \& Breiman, 2009; Luby, 2013; Banwell, Ulijazsek \& Dixon, 2013). Patterns of human knowledge; shared traits transmitted through social learning, are characteristics of culture. Traits can be ideologies, attitudes toward behavior, material culture and survival strategies that particular groups hold in common. Within one "culture" there are many sub-cultures built around religion, economics, politics or other common interests. Effective understanding of diseases and other misfortunes and the actions needed to be taken to prevent and treat them (including the way people frequent health facilities) are very often specific to a particular context and are influenced by religious and secular beliefs. Local beliefs and behaviors can contribute to disease transmission in ways that might promote, legitimize, routinize or even sanctify behaviors that elevates risk factors.

\subsection{Cultural Aspects and HIV}

A number of factors fuel the HIV/AIDS pandemic; sexual behavior in the form of multiple sexual partners spread over a disparate network, or behavior that stems out of livelihood insecurities, such as survival sex; preference for dry sex or intercourse without the use of condom; and other masculine models supporting multiple partner, risk taking and violence, are all contributing factors, with young women being particularly affected (ICF Macro, 2010; República de Angola, 2010; Republic of Botswana, 2010; Republic of Namibia, Ministry of Health and Social Services, 2010; Republic of Zimbabwe, 2010). Women bear most of the weight of HIV/AIDS infection because of their limited possibilities to make free choice due to gender inequalities that stem from both cultural aspects and from poverty. In sub-Saharan Africa, women constitute $60 \%$ of people living with HIV although they are underrepresented in HIV research (http://www.who.int/gender/hiv_aids/en/). In some countries, HIV infection rates can be five times higher among girls than among boys (http://www.unicef.org/esaro/5482_HIV_prevention.html). Beliefs and practices are always fluid - adapting and changing in response to new circumstances - but they can also provide remarkably strong barriers to change. In particular, barriers can stem out of ideologically conservative ideas both those that see abstinence as the only moral means for prevention against HIV/AIDS, for example, and those that see the power to affect disease and it's outcomes as lying in the hands of God or ancestral spirits. Barriers can also stem out of structural factors such as poverty or isolation. Gender and cultural aspects have been identified as a major issue in relation to the prevention and impact mitigation of HIV\&AIDS (UNAIDS, 2009). 


\subsection{Nutritional Practices}

Women and men play different roles in nutrition and are affected differently. Women have an important role to play as food producer, food provider and carer of the sick and the elderly. Women are given the responsibility, but often not the means (decision, economic, knowledge, etc.) to ensure optimal nutrition for themselves and their children. Men and women face different nutritional needs during their life cycle. In some population groups and regions of the world, as is the case in India, (Sivakumar, 2008) or South Africa (Oxfam, 2014) girls and women are disadvantaged in relation to boys in terms of food intake, thus putting them at risk of experiencing health problems and becoming malnourished adolescents and mothers. Women are usually more affected by anemia (De Benoist, McLean, Egli \& Cogswell, 2008) and obesity than men (Kanter \& Caballero, 2012). Overall, the prevalence of undernutrition rate are similar between adult men and women, except for South East Asia were prevalence rate are higher for women and differences are exceptionally large in some communities (Nubé \& Van Den Boom, 2003). Due to their reproductive role women face the biological burden to give birth and breast-feed with all the associated health consequences. They also face the social burden of feeding the babies and children. Widespread nutrition deprivation among women perpetuates an inter-generational cycle of nutrition deprivation in children. Chronically malnourished mothers with limited access to adequate prenatal, delivery, and postnatal care are at increased risk of delivering undernourished babies. These, in turn, are at greater risk of limited growth and development, to suffer higher rates of infection, and face a greater probability of death from infection and undernutrition. Undernutrition negatively influences intellectual and physical capacities, affects labour productivity and the ability of the undernourished to make a living, thus establishing a poverty and undernutrition cycle. In such cases, gender inequality is also a cause of poor health both for the mothers and for their children. Gender inequalities are a cause and a consequence of malnutrition.

But nutrition is not a household and an individual issue. It is a societal problem embedded in the fabric of social inequalities and national policies. Obesity, undernutrition and many other diseases (diabetes, asthma, and heart diseases, etc.) are all directly related to how humans interact with the local ecosystem. A recent report from Oxfam (2014) shows how in South Africa, a food secure country, malnutrition has two faces, with childhood stunting representing $26.5 \%$ and the percentage of obese women being amongst the highest of the world at $42 \%$ (Oxfam, 2014). Undernutrition, overweight and obesity might be found in the same community and the same household. They are different consequences of the same problem, a societal disease connected to the way people live. Women headed households are more vulnerable to food insecurity than male headed households. The causes of the problems are multiples and interconnected. In South Africa, food industry is dominated by very few corporates with large commercial agribusinesses controlling the production, the processing and the distribution of food (Oxfam, 2014). Households have very limited access to land and water for cultivation and gardening. Unemployment (23\% among men and $27 \%$ among women), low wages and the lack of money to buy food are additional factors (Oxfam, 2014). Food is available but unaffordable. Often the only food available in super market is of low quality (even expired food with inadequate labeling) with no fresh food and vegetables. The raising of the price of food, electricity and petrol in 2013/14 has worsened the situation. In South Africa, as in other countries with similar problems, it is crucial to develop whole food chains in an holistic and transdisciplinary manner in support to sustainable livelihood and nutrition systems (including child care, health and water and sanitation). The approaches need to include political will to coordinate and implement adequate policies involving all stakeholders, including the food industry, and tackling issues such as the access to land and work, support to agriculture and marketing, descent salaries, addressing gender inequities and supporting people facing hunger.

There is an emerging consensus as well as an increasing bulk of evidence that it is necessary to address gender inequality to contribute to alleviating hunger, poverty and unemployment. A recent literature review shows that there have been very few agricultural interventions linking food production, nutritional and health outcomes and that most of the research has failed to show a direct link between increased production and improved nutritional status both directly and indirectly (Hawkes et al., 2012; Dorward \& Dangour, 2012, Masset et al, 2012). Additionally, available data indicate that gender inequality and cultural issues have been inadequately addressed in most research linking agriculture and nutrition (Hawkes et al., 2012:11). While policy development aims to be based on sound "evidence", these "evidences" are often missing where food and agriculture is concerned in Africa (Sumberg et al, 2013).

\section{Human, Animal and Plant Diseases Impact Men and Women Differently}

Men and women tend to impact the environment differently and also are impacted differently by it. The way human, animal and plant diseases impact men and women varies. Men and women carry out different activities as a result of gender norms. In rural areas, men are more likely to be involved in hunting, commercial cropping, large 
livestock production and formal employment, while women are gathering wood, edible and medicinal plants, caring for small livestock, and producing subsistence food (Doss, 2002). Livestock, crops, natural resources and activities, are thus "gendered" as well as the risk to contract disease as a result of these activities.

The primary source of livelihood for $48 \%$ of women worldwide is agriculture. Women make up $43 \%$ of the agricultural labour force in developing countries and account for two-thirds of the world's 600 million poor livestock keepers (http://www.fao.org/gender/infographic/en/). In Sub-Saharan African countries the contribution made by women to agriculture is critical as they provide $60 \%$ to $80 \%$ of the labour for food production and most of the post-harvest management (Mehra \& Rojas, 2008). While women in developing countries engage in both commercial and subsistence cropping, their role of providing food via subsistence cropping is particularly important. They often manage species-rich production systems adapted to drought and pests while male dominated production tends to be oriented towards a single cash crop. While the ecological context affects human, animal and plant development, similarly, poor human, animal and poor plant health impacts negatively on human nutrition and wellbeing. Not only do different social groups bear these consequences differently, but gender can also influence their distribution. Gender inequality and cultural issues have been inadequately addressed in most research linking agriculture and nutrition (Hawkes et al., 2012). In fact, most agricultural interventions reviewed showed increased food production but no improvement in nutrition or health within the households because neither nutritional education nor gender issues are invested in (Berti et al., 2004). Within the context of climate change and increasing poverty and food insecurity, improving both food production and nutritional and health outcomes are recognised as being of major relevance (FAO, 2012; World Hunger, 2012). Food production, nutrition and health are interconnected. As food producer, provider of food and as carer of the sick and the old, women have an important role to play in all these areas.

When considering human health, men and women have distinguishable exposure as a result of patterns of activities resulting from socially defined gender roles that influence the timing of the contact with the infectious agent within the cycle of the outbreak. Although it might differ from context to context, women are often responsible for the nutrition and health of their households, especially when preparing daily meals and taking care of the sick and the elderly, both as paid professionals or as unpaid and untrained family or community members. They are thus the most affected in instances of poor health in their household and without access to media and information they run a higher risk of being infected in the case of contagious diseases. Additionally, women assume most of the emotional weight of caring for the sick, often without any psychological support. Girls and women also carry most of the weight of the economic impact of poor health in the household, sacrificing their education, their careers or their income activities to care for the sick as this is often considered their responsibility. This has been well-reported in relation to HIV/AIDS (Esplen, 2009a, 2009b). The common practise of withdrawing girls from school to care for a sick family member, tends to reproduce a vicious circle of poor education, poverty and low social and economic power.

\subsection{Ebola Virus and Gender}

Ebola virus is a zoonotic disease, often fatal in humans and primates and is transmitted through contact between animals, animals and humans and between humans (http://www.who.int/csr/disease/ebola/en/) Information available on the Ebola hemorrhagic fever virus published by World Health Organization (2007) shows gender differences in the transmission route and in the timing of the infection. During the 2001-2002 outbreak that occurred in the Congo and Gabon, men in contact with infected primates, often hunters, became infected at the onset of the outbreak, but as the outbreak progressed, more women were exposed due to specific gender roles such as caring for sick people either at home, in the health center, as traditional healers or as midwives (Table 3). In Gulu, in Uganda the number of female cases outnumbered the number of male during the whole duration of the 2001-2002 outbreak (WHO, 2007). While the differences between the two outbreaks are not clearly understood, this data highlights the fact that the context in which disease and gender intersect varies from place to place and time to time.

During an outbreak of Ebola Hemorrhagic Fever in Kikwitt in the Democratic Republic of Congo in 1995, a large number of women were infected in the maternity clinic (WHO, 2007). Thus, maternity clinics and hospitals can be a space where nosocomial spread is observed and the outbreak amplified. Health professionals and people more likely to frequent the facilities are at increased risk of contracting the infectious disease at an early stage of the outbreak when preventive measures are not yet in place.

In some communities such as in Uganda, it was found that old women were responsible for caring for the sick and performing the cleansing of the dead body. This was both due to established cultural practices and as a way of preventing the younger generation from being exposed to the risk of contracting the disease (Helmett \& Amola, 
2003; WHO, 2007). Thus, not only gender and the role of the person, but also his/her age can be an important risk factor that needs to be taken into consideration. Table 1 summarizes the different transmission routes related to the different gender roles and their occurrence during the outbreak cycle.

Table 1. Difference in exposure to the Ebola hemorrhagic fever virus by men and women

\begin{tabular}{|c|c|c|c|}
\hline Transmission route & Gender role & Human group affected & Period of the outbreak cycle \\
\hline From infected primate & Hunting & Adult male & Onset of the outbreak \\
\hline From infected persons & Caring for sick people & Female youth, adult and elder women & Successive phase of the outbreak \\
\hline From infected persons & Caring for sick people & Health care staff usually mainly female & Successive phase of the outbreak \\
\hline From infected persons & Caring for sick people & Traditional healers and midwives & Successive phase of the outbreak \\
\hline From infected persons & No specific gender role & Sick patients in hospital & Successive phase of the outbreak \\
\hline From infected persons & Preparing the body of the death & Usually women, influenced by gender and cultural norms & Successive phase of the outbreak \\
\hline
\end{tabular}

Source: WHO, 2007 and http://www.cdc.gov/ncidod/dvrd/spb/mnpages/dispages/ebola/ebolatable.htm

\subsection{Bubonic Plague and Gender}

In animal reservoirs, specifically those with rodents, Bubonic plague circulates when the fleas bite a rodent that itself has been infected by the bite of a flea carrying the disease. When infected fleas bite humans to feed from their blood, these in turn become infected by the disease. In the Lushoto district, in Tanzania, most girls were sleeping on mats on the floor while boys were sleeping on beds (Kilonzo, Mvena, Machangu \& Mbise, 1997). Due to this gender difference, girls were exposed to higher risk of being bitten by fleas as these can be found in dark and humid areas in the cracks and crevices of the floor. The adoption of prevention and treatment measures were often hampered as the causes of ongoing outbreaks of plague were often attributed by some people to witchcraft and bad spirits (Kilonzo \& Mhina, 1982), which again has a more direct impact on the women and girls.

\subsection{Newcastle Disease and Gender}

Newcastle disease, considered the most important chicken disease worldwide (Alexander et al., 2004; Samal, 2011), affects rural economies and those living in poverty, especially impacting the lives of the members of the community who are already most vulnerable. While, for households in the highest wealth quintile, losing five chickens a year to Newcastle disease might be irrelevant, for the poorest households it makes an important difference in terms of access to both income and food. It tends to specifically bear upon women who are very often responsible for the chickens and for controlling the use of the revenue resulting from their sale. Very often chickens are the only livestock assets over which women have any control. As women use $90 \%$ of their revenue in support of their household and community, with men only reinvesting between 30 and $40 \%$ (OECD, 2009), the loss of women's revenue greatly alters the level of household poverty and food security. In the wake of HPAI subtype $\mathrm{H} 5 \mathrm{~N} 1$ pandemic, millions of poultry have been killed or slaughtered and the livelihoods of many households, and women in particular, severely affected (Alders, Awuni, Farrell, Bagnol \& de Haan, 2013; FAO, 2009b). Widespread culling of family poultry has impacted on vulnerable households, contributing to increased stunting in children under five in Egypt (FAO, 2009b) and decreased enrolment of girls in school in Turkey post HPAI H5N1 control activities (Bagnol, 2009).

It is noteworthy that of all of the paramyxoviruses of animals listed above, Newcastle disease has the greatest impact on women and vulnerable households, yet it remains endemic in most African and SE Asian countries and its prevention and control receives limited attention in comparison to Rinderpest and PPR, perhaps because historically, the veterinary profession has been a male-dominated arena (Lofstedt, 2003). In the last decade or so, social scientists and gender specialists have been brought in to work with ruminant health programs but rarely has an objective assessment been made in relation to whether this is the best way to strengthen assets more likely to be under the control of women. Village chickens, for example, are the most commonly owned livestock in sub-Saharan Africa and they are frequently the only livestock asset owned by the most vulnerable households and over which women have some control. Very limited research and development is focused on village chickens and that the International Livestock Research Institute within the Consultative Group on International Agricultural Research has only recently commenced limited research on poultry. 


\subsection{Plant Diseases (African Cassava Mosaic Virus and Mycotoxins) and Gender}

Subsistence farmers in the tropical regions of Africa grow cassava as their major crop. Cassava is particularly resistant to drought (Okogbenin et al., 2013) and excess product provides a source of income for poor households. African Cassava Mosaic Virus is a devastating disease, widespread in Africa (Legg \& Fauquet, 2004), often destroying much of the harvest with significant impact, on subsistence farming and women's income. (Thro et al., 1998).

Mycotoxins are highly toxic metabolites produced pre and post-harvest by fungal pathogens such as Aspergillus flavus, and Aspergillus parasiticus and are present in a wide range of staple foods such as grains, oilseeds and groundnuts in tropical environments (Shuaib et al., 2010). Aflatoxin contamination is estimated to affect $25 \%$ of the global food supply with 4.5 billion people exposed to high, unacceptable levels, mostly in developing countries (Williams et al., 2004). Chronic aflatoxin exposure causes cirrhosis or carcinoma of the liver in humans and animals (Wagacha and Muthomi, 2008), adverse birth outcomes (Shuaib, et al., 2010) and growth impairment (Khlangwiset et al., 20011). Aflatoxins can also permeate through the skin. Women and children are the most vulnerable to this as they are more often in contact with the grains. Acute aflatoxin also occurs periodically, with the worst case of 125 deaths and 317 sickened being recorded in Kenya in 2004, when contaminated home grown maize entered the local supply chain (Wagacha \& Muthomi, 2008). While aflatoxins can contaminate crops pre-harvest, high humidity and temperatures post-harvest, coupled with inadequate drying and storage promotes toxin production, inextricably linking low socio-economic status to the likelihood of mycotoxin exposure.

Women are responsible for 80 percent of the work associated with food storage and transport from farm to village, and 60 percent of harvesting and marketing. Thus, women are primarily exposed to aflatoxins, potentially ingesting high levels and passing to children while in utero or through breastmilk (Shuaib et al., 2010).

Mitigation of aflatoxin production pre-harvest can be achieved by better irrigation practices, use of biopesticides, and use of technologies such as Aflasafe ${ }^{\mathrm{TM}}$ which competitively excludes the toxin producing Aspergillus species (EIRD, 2013). Similarly post-harvest reduction of aflatoxins can be obtained by improved drying and storage (Kimatu et al., 2012). The significant contribution of women in both pre and post harvest activities, strongly suggests that policies and extension practices that target women will support interventions that reduce aflatoxin poisoning.

\section{Biological Differences Between Men and Women}

Biological factors influence differences in exposure, infection and mortality rates of men and women and constitute the fourth factor of the conceptual framework of this paper. Biological distinctions between men and women exist not only in terms of the constitution of the whole body, but also in terms of the constitution of the organs and cells. The variation in the risk of infection between genders can also be related to biological characteristics such as menstruation, pregnancy and lactation and to different stages in the life cycle.

The likelihood of contracting a disease during the life cycle, and the outcome of this disease, varies according to various factors. Table 2 presents the main differences between male and female susceptibility, exposure, treatment and morbimortality in relation to infectious diseases during the life cycle. For example, the immunity level is lower in childhood and among the elderly. Gender difference also influences the course and outcome of the disease. There is a difference, for example, between male and female children in relation to immunization or nutritional status and how quickly appropriate care is provided. Pregnancy and breast-feeding are conditions that are rarely taken into adequate consideration but in which, susceptibility, exposure, symptoms, treatment impact and morbimortality varies from other groups (WHO, 2007).

While some groups can be more prone to be infected by a disease some others, such as pregnant and breast feeding women, also find themselves in a situation where the side effects of the medicine on both them, the fetus and the breast feeding child are not always well known (WHO, 2007).

\subsection{Biological Differences in Relation to HIV/AIDS Infection}

One example of a biological difference that influences the exposure, infection and mortality rates of men and women is the case of the human immunodeficiency virus and acquired immunodeficiency syndrome (HIV\&AIDS) where women face greater susceptibility to HIV infection through heterosexual sexual relations than men (Mastro \& de Vincenzi, 1996). Although biological distinctions alone cannot explain the variation in prevalence of the disease between men and women, several biological characteristics are known to be influential: the cervix of a young girl is less mature and more vulnerable to infection, there is a greater possibility of lesions occurring in the female genital track than in the male track, the female genital track has a greater surface area than the male track and there is a higher concentration of HIV in semen than in vaginal fluid (UNAIDS, 2000; UNIFEM, 2001). In 
addition to these aspects, conception and pregnancy can also be factors contributing to increased risk of infection for HIV negative women in serodiscordant couples (WHO, 2012:44). Also, in relation to cell composition, there are two $\mathrm{X}$ chromosomes in female cells and one $\mathrm{X}$ and one $\mathrm{Y}$ in male cells, and the $\mathrm{X}$ cell is known for its role in the immune system (WHO, 2007:3). Although it is not yet known how this difference influences predisposition, resilience and disease expression it is nonetheless worth noting and an area worthy of further research.

Table 2. Differences between male and female during the life cycle in relation to infectious diseases

\begin{tabular}{|c|c|c|c|c|}
\hline Life cycle & Susceptibility & Exposure & Treatment & Morbimortality \\
\hline Infant & $\begin{array}{l}\text { Female infants have a } \\
\text { stronger immune } \\
\text { system }\end{array}$ & $\begin{array}{l}\text { Similar exposure for } \\
\text { male and female } \\
\text { infants }\end{array}$ & $\begin{array}{l}\text { Male infants are more } \\
\text { likely to be treated } \\
\text { outside of the } \\
\text { household }\end{array}$ & $\begin{array}{lll}\text { Male } & \text { infants } & \text { have } \\
\text { higher } & \text { mortality } & \text { than } \\
\text { female } & & \end{array}$ \\
\hline Children & $\begin{array}{l}\text { Male and female } \\
\text { immunization }\end{array}$ & $\begin{array}{l}\text { Boys tend to spend } \\
\text { more time outside } \\
\text { the house }\end{array}$ & $\begin{array}{l}\text { Boys are more likely } \\
\text { to be treated outside of } \\
\text { the household }\end{array}$ & $\begin{array}{l}\text { Disease specific } \\
\text { differences in both } \\
\text { severity and outcome }\end{array}$ \\
\hline Adults & $\begin{array}{l}\text { Differences in } \\
\text { exposure between } \\
\text { men and women }\end{array}$ & $\begin{array}{l}\text { Gender roles often } \\
\text { limit women to } \\
\text { activities within the } \\
\text { household and to } \\
\text { men essentially to } \\
\text { activities outside }\end{array}$ & $\begin{array}{l}\text { Women have less } \\
\text { access than men to } \\
\text { health services for } \\
\text { themselves. } \\
\text { Research often uses } \\
\text { male cases and there is } \\
\text { less evidence of } \\
\text { results from } \\
\text { treatments on women }\end{array}$ & $\begin{array}{l}\text { Disease specific } \\
\text { differences in both } \\
\text { severity and outcome }\end{array}$ \\
\hline $\begin{array}{l}\text { Pregnant } \\
\text { and } \\
\text { lactating } \\
\text { women }\end{array}$ & $\begin{array}{l}\text { Important changes in } \\
\text { the immune system - } \\
\text { but there is a } \\
\text { knowledge gap in this } \\
\text { respect. }\end{array}$ & $\begin{array}{l}\text { Greater exposure to } \\
\text { health unit with } \\
\text { more potential sick } \\
\text { individuals }\end{array}$ & $\begin{array}{l}\text { Some treatments are } \\
\text { harmful for pregnant } \\
\text { women and their fetus } \\
\text { or breastfeeding } \\
\text { mother or child. } \\
\text { Limited research on } \\
\text { treatment of pregnant } \\
\text { women, resulting in } \\
\text { insufficient } \\
\text { information on their } \\
\text { impact. }\end{array}$ & $\begin{array}{l}\text { Some diseases adversely } \\
\text { affect pregnant women, } \\
\text { their fetus or } \\
\text { breastfeeding mother or } \\
\text { child. }\end{array}$ \\
\hline $\begin{array}{l}\text { The } \\
\text { elderly }\end{array}$ & $\begin{array}{l}\text { Poor immune system } \\
\text { for male and female }\end{array}$ & Lack of evidence & $\begin{array}{lr}\text { Diagnosis } & \text { more } \\
\text { difficult due to } \\
\text { atypical presentation } \\
\text { in both male and } \\
\text { female }\end{array}$ & $\begin{array}{l}\text { More women than men } \\
\text { in this age group. Little } \\
\text { information on gender } \\
\text { difference. }\end{array}$ \\
\hline
\end{tabular}

Adapted from: WHO, 2007.

\section{Discussion: Implication of Gender Issues for Disease Surveillance, Control and Response}

Men and women impact the environment differently and are affected differently. Human, animal and plant diseases affect and impact men and women differently. This is due to a web of interconnected circumstances, from which we have distinguished the four key contributing factors. First, the socio-economical, cultural, legal and political factors that influence how men and women have different impacts on the environment. Secondly, as a result of their different power, role and status in society men and women face specific health risks. Thirdly, ecological degradation, plant and animal diseases affect men and women differently. Fourthly, biological factors influence differences in exposure, infection rates and mortality rates of men and women during their life cycle. Depending on the local contexts, these four factors contribute in a variety of ways in defining different risks for 
men and women. Taking several examples relating to human, animal and plant health we have shown how gender does not only impact on the risk of contracting diseases but also influences the likelihood of accessing information and treatment, and of obtaining resources to get access to treatment. Gender also influences the evolution of disease and disorders and treatment outcome. Gender may also determine the impacts of a specific disease or disorder on men and women's livelihood, their health and the health of their household and the implementation of prevention measures or of biosecurity and eco-security measures.

Ecohealth problems originate in complex interactions between factors that reveal the extent to which successful solutions must cross research disciplines (Barbés-Blásquez, Oestreicher, Mertehs \& Saint-Charles, 2014). All the institutions involved need to apply a gender sensitive analysis and function in a gender sensitive manner. Responding effectively to ecohealth issues and emerging infectious diseases requires engagement of and coordination with a diversity of professions and stakeholders in both human and animal health, as well as social and environmental sciences. To preserve the environment in a sustainable way it is of extreme importance to pay close attention to the impact of disparities between women and men on access to resources and opportunities, how men and women impact the environment and how they are impacted by degraded ecosystems. Sustainable development and effective prevention strategies must aim to foster women's empowerment and effective participation. Not only because it is more effective and sustainable but also because life chances should not be pre-determined at birth by the sex of the person or any other reason. Thus it is both a human right and a development issue. This implies involving women and men as partners and allies in formulating and pursuing strategies for more equal societies. Gender and social equity are already part of the ecohealth agenda (Charron, 2011) and need to be supported by gender sensitive policies, guidelines and procedures developed with national and international agencies.

Possible interventions to mitigate inequalities and strengthen the effectiveness of the ecohealth paradigm should include improving incorporation of social sciences and gender equity in the training of professionals and ensuring that ecohealth training programs include case studies that highlight the importance of recognizing the contribution of gender when investigating and controlling disease outbreaks. Higher institutions of learning can and must play a key role in transforming and shifting the response and control of emerging pandemics towards a gender sensitive ecohealth approach. However, institutions of higher learning have tended to reflect local gender norms of the society in which they are located. Supporting academic institutions with multidisciplinary applied training and experience in animal, human and environmental health threats with a focus on gender is crucial. Courses delivered in a gender-sensitive and transdisciplinary manner can provide students with an overview of the different tools available to carry out a gender analysis and implement disease surveillance, response, prevention and control. Participatory methods should be used to allow participants to integrate their experience and knowledge with the skills learned during the course and also to motivate them to apply such methodologies in their own work.

For the development of gender sensitive disease prevention, surveillance and response approaches. The epidemiology of risk and vulnerability for all groups must be analyzed and the economic, legal and sociological contexts that fuel the spread of the disease, increase the burden of care, and prevent effective treatment and support (UNAIDS, 2009) must be taken into account. It is important to be able to understand disease epidemics and responses in terms of gender in order to better meet the needs of all groups within a community. It is also critical to collect other relevant socio-cultural, economic and legal data in addition to carrying out gender analyses in all phases of programming and action. This enables a better understanding of the varying impacts of infectious and emerging diseases and disorders at all levels of society where women, men, girls and boys are viewed as people that are or can be infected and affected by the diseases or disorders in various ways. The use of relevant sex and age-disaggregated data helps to build the knowledge necessary for programming action and for developing gender-responsive prevention and response interventions. All data such as infection rate and case-fatality should be disaggregated by gender. Similarly, the profile of symptoms for men and women should also be collected separately. Women and men should be enabled to analyze the data and to decide the actions to be taken.

\section{Conclusion}

Although there is an increasing awareness of the importance of addressing gender in relation to health, agriculture, livestock and ecology in research, training and interventions, these issues are not yet fully and adequately integrated into all programs. This paper argues that full integration would result in significantly improved results in both the medium and long term. The active involvement of social scientists in ecohealth activities is essential to ensure that the different knowledge held by men and women, their roles, and the impact of these are understood and used to deliver effective, efficient and sustainable ecohealth programs. 


\section{Acknowledgements}

The authors would like to acknowledge the support given to our international research and development by many donors including Australian Centre for International Agricultural Research (ACIAR) which is currently funding a food and nutrition security project (FSC/2012/023) in which we are all involved. Thanks go to all those researchers, extension workers and farmers in many countries with whom the authors have collaborated over the past two decades.

\section{References}

Alders, R., Awuni, J. Farrell, P., Bagnol, B., \& de Haan. N. (2013). Impact of Avian Influenza on Village Poultry Production Globally. Ecohealth, 11(1), 63-72. http://dx.doi.org/10.1007/s10393-013-0867-x

Alexander, D. J., Bell, J. G., \& Alders, R. G. (2004). Technology review: Newcastle Disease with Special Emphasis on its Effect on Village Chickens. FAO Animal Production and Health Paper 161. Rome, FAO.

AVMA, The American Veterinary Medical Association. (2008). One Health Initiative Task Force. One Health: A New Professional Imperative. July 15, 2008. Retrieved from https://www.avma.org/KB/Resources/Reports/ Documents/onehealth_final.pdf .

Bagnol, B. (2009). Gender issues in small-scale family poultry production: experiences with Newcastle Disease and Highly Pathogenic Avian Influenza control. World's Poultry Sciences Journal, 65, 231-240. http://dx.doi.org/10.1017/S0043933909000191

Banwell, C., Ulijazsek, S., \& Dixon, J. (Eds.). (2013). When Culture Impacts Health. Global Lessons for Effective Health Research. Amsterdam: Elsevier. Retrieved from http://store.elsevier.com/When-CultureImpacts-Health/isbn-9780124159211/

Barbés-Blásquez, M., Oestreicher, J. S., Mertehs, F. \& Saint-Charles, J. (2014). Ecohealth and Resilience Thinking: a Dialog from Experiences in Research Practice. Ecology and Society ,19(2), 24.

Berti, P. R., Krasevec, J., \& FitzGerald, S. (2004) A review of the effectiveness of agriculture interventions in improving nutrition outcomes. Public Health Nutrition, 7(5), 599-609. http://dx.doi.org/10.1079/ PHN2003595

Blum, L. S., Khan, R., Nahar, N., \& Breiman, R. F. (2009). In-depth Assessment of an Outbreak of Nipah Encephalitis with Person-to-person Transmission in Bengladesh: Implications for Prevention and Control Strategies. The American Journal of tropical Medicine and Hygiene, 80, 96-102.

Braidotti, R., Charkiewicz, E., Hausler, S., \& Wieringa, S. (1994). Women, The Environment and Sustainable Development, Towards a Theoretical Synthesis. London: Zed Books.

Charron, D. F. (2011). Ecohealth Research in Practice. Innovative applications of an Ecosystem Approach to Health. Ottawa: CRDI, Springer.

De Benoist, B., McLean, E., Egli, I., \& Cogswell, M. (eds). (2008). Worldwide prevalence of anemia 1993-2005: Who global database on anemia. Geneva: WHO.

De Sousa Santos, B. (ed.). (2008). Another Knowledge is Possible. Beyond Northern Epistemologies. London: Verso.

Doss, C. R. (2002). Men's crops? Women's crops? The Gender Patterns of Cropping in Ghana. World Development, 30, 1987-2000. http://dx.doi.org/10.1016/S0305-750X(02)00109-2

Dutta, S. (2005). Energy as a Key Variable in Eradicating Extreme Poverty and Hunger: A gender and Energy Perspective on Empirical Evidence on MDG \#1. Discussion Paper DFID/ENERGIA project on Gender as a Key Variable in Energy Interventions. London: DFID.

EIARD. (2013). Tackling Killer Aflatoxins in African Food Crops. WRENmedia February. Retrieved from http://eiard.org/media/uploads/File/Casestudies/2013SDCfunded/IITATacklingkilleraflatoxinsinAfricanfoo dcrops.pdf

Esplen, E. (2009a). Gender and Care, Overview Report. Brighton: Bridge. Retrieved from http://www.bridge. ids.ac.uk/reports/cep_care_or.pdf

Esplen, E. (2009b). Gender and Care. Supporting Resource Collection. Brighton: Institute of Development Studies. Retrieved from http://huairou.org/sites/default/files/Gender\%20and\%20Care-\%20Supporting\%20 Resources\%20Collection.pdf. 
FAO. (1995). Improving the Relevance and Effectiveness of Agricultural Extension Activities for Women Farmers. Rome: FAO. Retrieved from http://www.fao.org/docrep/V4805E/V4805E00.htm

FAO. (1996). Towards Sustainable Food Security. Women and Sustainable Food Security. Rome: Women in Development Service (SDWW) FAO Women and Population Division. Retrieved from http://www.fao.org/sd/fsdirect/fbdirect/FSP001.htm

FAO. (2009a). Gender Equity in Agriculture and Rural Development: A quick Guide to Mainstreaming in FAO's New Strategic Framework FAO. Rome: FAO. Retrieved from ftp://ftp.fao.org/docrep/fao/012/i1240e/ i1240e00.pdf.

FAO. (2009b). The State of Food Insecurity in the World: Economic Crises - Impacts and Lessons Learned. Food and Agricultural Organisation of the United Nations, Rome.

FAO. (2012). The State of Food Insecurity in the World 2012. Retrieved from http://www.fao.org/docrep/ 016/i3027e/i3027e00.htm?

FAO. (no date). The Female Face of Farming. Farmers, Workers, Entrepreneurs, Care-giver, Bread-winners, Bread-makers, Mothers, Wives, Daughters. Retrieved from http://www.fao.org/gender/infographic/en/

Farmer, P. (1999). Infections and Inequalities. Berkeley: University of California Press.

Green, C. E. (1999). Indigenous Theories of Contagious Disease. Walnut Creek CA: Altamira Press.

Hawkes, C., Turner R., \& Waage, J. (2012). Current and Planned Research on Agriculture for Improved Nutrition: A Mapping and a Gap Analysis. Aberdeen: Leverhulme Centre for Integrative Research on Agriculture and Health (LCIRAH) and Centre for Sustainable International Development, University of Aberdeen.

Hewlett, S. B., \& Amola, R. P. (2003). Cultural Contexts of Ebola in Northern Uganda. Emerging Infectious Diseases, 9(10), 1242-1248. http://dx.doi.org/10.3201/eid0910.020493

ICF Macro. (2010). HIV Prevalence Estimates from the Demographic and Health Surveys Updated June 2010. Calverton, Maryland: ICF Macro.

ILRI. (2010). After Successful Eradication of Rinderpest, African Researchers now Focus on Peste des Petits Ruminants, the Most Urgent Threat to African Livestock. ILRI News, 22 November 2010. International Livestock Research Institute. Retrieved from http://www.ilri.org/ilrinews/index.php/archives/3901

Kanter, R. \& Caballero, B. (2012). Global Gender Disparities in Obesity: A Review. Advances in Nutrition, 3, 491-498. http://dx.doi.org/10.3945/an.112.002063

Khlangwiset, P., Shephard, G. S, \& Wu, F. (2011). Aflatoxins and Growth Impairment: A Review. Critical Reviews in Toxicology, 41, 740-755. http://dx.doi.org/10.3109/10408444.2011.575766

Kilonzo, B. S., \& Mhina, J. I. (1982). The First Outbreak of Human Plague in Lushoto District, North-East Tanzania. Transactions of the Royal Society of Tropical Medicine and Hygiene, 76, 172-177. http://dx.doi.org/10.1016/0035-9203(82)90269-3

Kilonzo, B. S., Mvena, Z. S. K., Machangu, R. S., \& Mbise, T. J. (1997). Preliminary Observations on Factors Responsible for Long Persistence and Continued Outbreaks of Plague in Lushoto District, Tanzania. Acta Tropica, 68, 215-227. http://dx.doi.org/10.1016/S0001-706X(97)00096-X

Kimatu, J., McConchie, R., Xie, X., \& Nguluu, S. (2012). The Significant Role of Post-Harvest Management in Farm Management, Aflatoxin Mitigation and Food Security in Sub-Saharan Africa. Greener Journal of Agricultural Sciences, 2(6), 279-288.

Latour, B. (2012). Enquête sur les Modes d'Existence. Une Anthropologie des Modernes. Paris: La Découverte.

Legg, J. P., \& Fauquet, C. M. (2004). Cassava Mosaic Geminiviruses in Africa. Plant Molecular Biology, 56, 585-599. http://dx.doi.org/10.1007/s11103-004-1651-7

Lofstedt, J. (2003). Gender and Veterinary Medicine. The Canadian Veterinary Journal, 44, 533-535.

Luby, S. (2013) The Cultural Anthropological Contribution to Communicable Disease Epidemiology. In C. Banwell, S. Ulijazsek, \& J. Dixon (eds.), When Culture Impacts Health. Global Lessons for Effective Health Research. Amsterdam: Elsevier 2013. Retrieved from http://store.elsevier.com/When-CultureImpacts-Health/isbn-9780124159211/ 
Maass Wolfenson, K. D. (2013). Coping with the Food and Agriculture a Challenge: Smallholder's Agenda. Preparations and outcomes of the 2012 United Nations Conference on sustainable development [Rio +20]. Rome: FAO.

Mastro, T. D., \& de Vincenzi, I. (1996). Probabilities of Sexual HIV-1 Transmission. AIDS, 10(suppl A), S75-S82. http://dx.doi.org/10.1097/00002030-199601001-00011

Mehra, R., \& Rojas, M. H. (2009). Women, Food Security and Agriculture in a Global Marketplace: A Significant Shift. Washington: International Center for Research on Women.

Miguel, E., \& Kremer, M. (2004). Worms: Identifying Impacts on Education and Health in the Presence of Treatment Externalities. Econometrica, 72(1), 159-217. http://dx.doi.org/10.1111/j.1468-0262.2004.00481.x

Njuki, J. (2012). Linking Women Farmers to Markets: Patterns of Market Participation, Decision Making and Intra-household Income Management. Presented at the Global Conference on Women in Agriculture. New Delhi, India. Retrieved from http://www.slideshare.net/ILRI/linking-farmers-to-markets-jemimah-njuki

Nubé, M., \& Van Den Boom, G. J. (2003). Gender and Adult Undernutrition in Developing Countries. Ann Hum Biol., 30(5), 520-37. http://dx.doi.org/10.1080/0301446031000119601

OECD. (2009). DAC Guiding Principles for Aid Effectiveness, Gender Equality and Women's Empowerment. Gender Equality: Empowering Women so that Development is Effective. Paris: OECD. Retrieved from http://www.oecd.org/social/gender-development/42310124.pdf

Okogbenin, E., Setter, T. L., Ferguson, M., Mutegi, R., Ceballos, H., Olasanmi' B., \& Fregene M. (2013). Phenotypic Approaches to Drought in Cassava: Review. Frontiers in Physiology, 4, 1-15. http://dx.doi.org/ 10.3389/fphys.2013.00093

Oxfam. (2014). Hidden Hunger in South Africa. The Faces of Hunger and Malnutrition in a Food-Secure Nation. Oxford: Oxfam.

Paxton, P., Green, J., \& Hughes, M. (2008). Women in Parliament, 1945-2003: Cross-National Dataset, Inter-university Consortium for Political and Social Research, Ann Arbor, MI World Bank (2012) World Development Indicators.

Republic of Botswana. (2010). Progress Report of the National Response to the 2001 Declaration of the Committment on HIV and AIDS. Botswana Country Report 2010. Reporting Period 2008-2009. Gaberone: Ministry of Health.

Republic of Namibia, Ministry of Health and Social Services. (2010). United Nations General Assembly Special session (UNGASS) Country Report. Reporting Period 2008-2009. Windhoek: Ministry of Health.

Republic of Zimbabwe. (2010). United Nations General Assembly Special Session Report on HIV and AIDS. Follow-up to the Declaration of Commitment on HIV and AIDS. Zimbabwe Country Report. Reporting Period: January 2008 to December 2009. Harare: Republic of Zimbabwe.

República de Angola. (2010). Relatório sobre o Progresso do País para dar Seguimento aos Compromissos da Sessão Especial sobre VIH e SIDA da Assembleia Geral das Nações Unidas (UNGASS). 2008-2009. Luanda: INLS e Ministério da Saúde.

Saito, K. A., \& Spurling, D. (1992). Designing and Delivering Agricultural Extension for Women Farmers. Washington: The World Bank, Women in Development Division Population and Human Resources Department.

Samal, S. K. (2011). Newcastle Disease and Related Avian Paramyxoviruses. In The Biology of Paramyxoviruses (pp. 69-114). Norfolk: Caister Academic Press.

Semba, R. D., de Pee, S., Sun, K., Sari, M., Akhter, N., \& Bloem, M. W. (2008). Effect of Parental Formal Education on Risk of Child Stunting in Indonesia and Bangladesh: a Cross-sectional Study. Lancet, 371(9609), 322-328. http://dx.doi.org/10.1016/S0140-6736(08)60169-5

Shiva, V. (1989). Staying Alive: Women, Ecology and Survival in India. London: Zed Books.

Shiva, V. (1997). Women in Nature. In: Vaivanathna, N., Duggan, L., Nisonoff, L., \& Wiegersma, N. (Eds.). The Woman Gender and Development Reader (pp. 62- 67). London: Zed Books Ltd.

Shuaib, F. M. B., Ehiri, J., Abdullahi, A., Williams, J. H., \& Jolly, P. E. (2010). Reproductive health effects of aflatoxins: A review of the literature. Toxicology, 29, 262-270. 
Sivakumar, M. (2008). Gender Discrimination and womens' development in India. Retrieved from http://mpra.ub.uni-muenchen.de/10901/1/MPRA_paper_10901.pdf.

Smith, L., \& Haddad, L. J. (2000). Overcoming Child Malnutrition in Developing Countries. International Food Policy research Institute (IFPRI).

SOFA team \& Doss, C. (2011). The Role of Women in Agriculture. ESA Working Paper No 11-02. Rome: FAO, Agricultural Development Economics Division.

Thro, A. M., Roca, W., Iglesias, C., Henry, G., \& Ng, S. Y. C. (1998). Contributions of In-vitro Biology to Cassava Improvement. African Crop Science Journal, 6, 303-315. http://dx.doi.org/10.4314/acsj.v6i3.27803

UNAIDS. (2000). Report on the Global HIV/AIDS. Geneva: UNAIDS.

UNAIDS. (2009). Agenda for Accelerated Country Action For Women, Girls, Gender Equality and HIV. Operational Plan for the UNAIDS. Action Framework: Addressing Women, Girls, Gender Equality and HIV. Geneva: UNAIDS.

UNICEF. (no date) Child Undernutrition in India: A Gender Issue. Speech by UNICEF Country Representative Karin Hulshof as part of a panel on Undernutrition and Gender in India chaired by the The Ministry of Women and Child Development. http://www.unicef.org/india/reallives_5901.htm

UNIFEM. (2001). Gender and HIV/AIDS prepared by UNIFEM. Building Local Knowledge about Women's Central Role in Halting the HIV/AIDS Epidemic. Presented at the Commission on the Status of Women (CSW), 45th Session (6-16 March 2001, New York).

United Nation. (2013). The Millennium Development Goals Report. New York: UN.

Wagacha, J. M., \& Muthomi, J. W. (2008). Mycotoxin Problem in Africa: Current Status, Implications to Food Safety and Health and Possible Management Strategies. International Journal of Food Microbiology, 124, 1-12. http://dx.doi.org/10.1016/j.ijfoodmicro.2008.01.008

Wamani, H., Tylleskär, T., Astrøm, A. N., Tumwine, J. K., \& Peterson, S. (2004). Mothers' Education but not Fathers' Education, Household Assets or Land Ownership is the Best Predictor of Child Health Inequalities in Rural Uganda. International Journal for Equity in Health, 3(1). http://dx.doi.org/10.1186/1475-9276-3-9

WHO. (2007). Addressing Sex and Gender in Epidemic-prone Infectious Disease. Geneve: WHO.

WHO. (2012). Guidance on Couples HIV Testing and Counselling including antiretroviral therapy for treatment and prevention in serodiscordant couples. Recommendations for a public health Approach. Geneve: WHO.

Williams, J., Phillips, T., Jolly, P., Stiles, J., Jolly, C., \& Aggarwal, D. (2004). Human Aflatoxicosis in Developing Countries: a Review of Toxicology, Exposure, Potential Health Consequences, and Interventions. American Journal of Clinical Nutrition, 80, 1106-1122.

World Hunger. (2012). 2012 World Hunger and Poverty Facts and Statistics. Retrieved from http://www.worldhunger.org/articles/Learn/world\%20hunger\%20facts\%202002.htm

\section{Copyrights}

Copyright for this article is retained by the author(s), with first publication rights granted to the journal.

This is an open-access article distributed under the terms and conditions of the Creative Commons Attribution license (http://creativecommons.org/licenses/by/3.0/). 